STATE OF FLORIDA

DEPART.MENT OF NATURAL RESOURCES

Virginia Wetherell, Exccutive Director

DIVISION OF RESOURCE MANAGEMENT

Jeremy A. Craft, Dircctor

FLORIDA GEOLOGICAL SURVEY

Walter Schmidt, State Geologist and Chicf

OPEN FILE REPORT NO. 47

LITHOLOGY AND PALYNOLOGY OF CAVE FLOOR SEDIMENT CORES FROM WAKULLA SPRING. WAKULLA COUNTY, FLORIDA

BY

FRAYK R, RUPERT

FLORIDA GEOLOGICAL SURVEY

Tallahassee

1991 
- (Q6)

C.2 


\section{Lithology and Palynology of cave floor sediment cores from Wakulla Spring, Wakulla County, Florida}

by

.Frank R. Rupert, P.G. 149

Abstract

Five shon boltom sediment cores taken in Wakulla Spring, Wakulla County, Florida, were described lithologically and sampled for palynological study. Four of the cores were recovered from sediments at the spring cave entrance (130 feet water depth). One core was taken in a fossil vertebrate bone bed, 280 feet distance into the main spring cave at a water depth of 240 feet. Sediments in the cores are composed of altemating intervals of quartz sand and calcilutice, containing freshwater diatoms, freshwater mollusk shells and plant remains. The predominant pollen present in all cores consists of a periporate variety cypical of the herb families Chenopodiaceae and Amaranthaceac. Arboreal flora, typical of the area surrounding the spring today, represent a very low percentage of the pollen assemblage in the cares. Clustered Chenopod-Amaranth type pollen observed in one core suggest minimal transpont prior to deposition, and indicate that the bottom sediments in the cave may be cssentially in sith. An absence of cxotic Jlora suggests a Quatemary age for the sediments.

\section{Introduction}

Wakulla Spring is a first-magnitude spring situated in Wakulla County, Florida, about 15 miles south of Tallahassee (Figure 1). Water flows from a single vent into a large spring pool, approximately 100 feet wide and 200 feet long, which forms the headwaters of the Wakulla River. The spring discharges regional ground water from the Floridan aquifer system.

The spring probably cvolved from a large post-Miocene sink which developed in the Oligocene and Miocene limestones underlying the area. Previous SCUBA explorations in the spring revealed the presence of a large cave or passage feeding the spring from depths in excess of 180 feet below mean sea level (Olsen, 1958; Rosenau et al., 1977). The cave typically measures about 40 feet high and 80 feet wide. Pleistocene vertebrate bones, charred wood, and numerous paleoindian artifacts have been discovered in the opter 1100 feet of the cave (Olsen, 1958). This led to speculation that the cave may have been dry during glacial periods of the Pleislocene.

During the last three months of 1987 fourteen cave divers, working under permit from the State of Florida, conducted the most extensive cxploration of the Wakulla cave system ever undertaken. This exploration revealed a sizable and complex conduit system feeding Wakulla Spring. Areas of the main cave were found to approach sizes of 60 feet high and 120 feet wide. At a point nearly 900 feet into the cave, the system splits into four separate feeder conduits, one of which extends over 4200 feet in from the cave entrance (Rupert and Spencer, 1988; Stone, 1989).

As part of the scientific studies performed during this project, the divers recovered a total of seven short cave floor sediment cores ranging in length from 9 inches to 31 inches. Five cores were taken in the floor of the mouth of the main spring cave; two others were recovered in a vertebrate bone bed situated approximately 280 feet into the main cave (Figure 1). Five of these seven cores, representing four cave entrance cores and one bone-bed core, are addressed in the present study.

\section{Methods}

The four cave-entrance sediment cores were recovered using a one and one-half inch diameter PVC pipe coring apparatus developed by William Wilson of Subsurface Evaluations Incorporated, Winter Springs, Florida (Figure 2). The core tube was pushed into the bottom sediments until it either bottomed against limestone bedrock or reached the 36-inch core tube length limit. The cohesiveness of the sediments generally allowed the core to remain intact in the PVC barrel as the coring device was withdrawn from the cave floor sediments. In some cases the sediment thickness excceded 36 inches, but core recovery was incomplete. The longest core recovered in this . study was 31 inches. Two short cores taken inside the cave in the outer bone bed were pushed into the sediment until they bottomed against bedrock. 


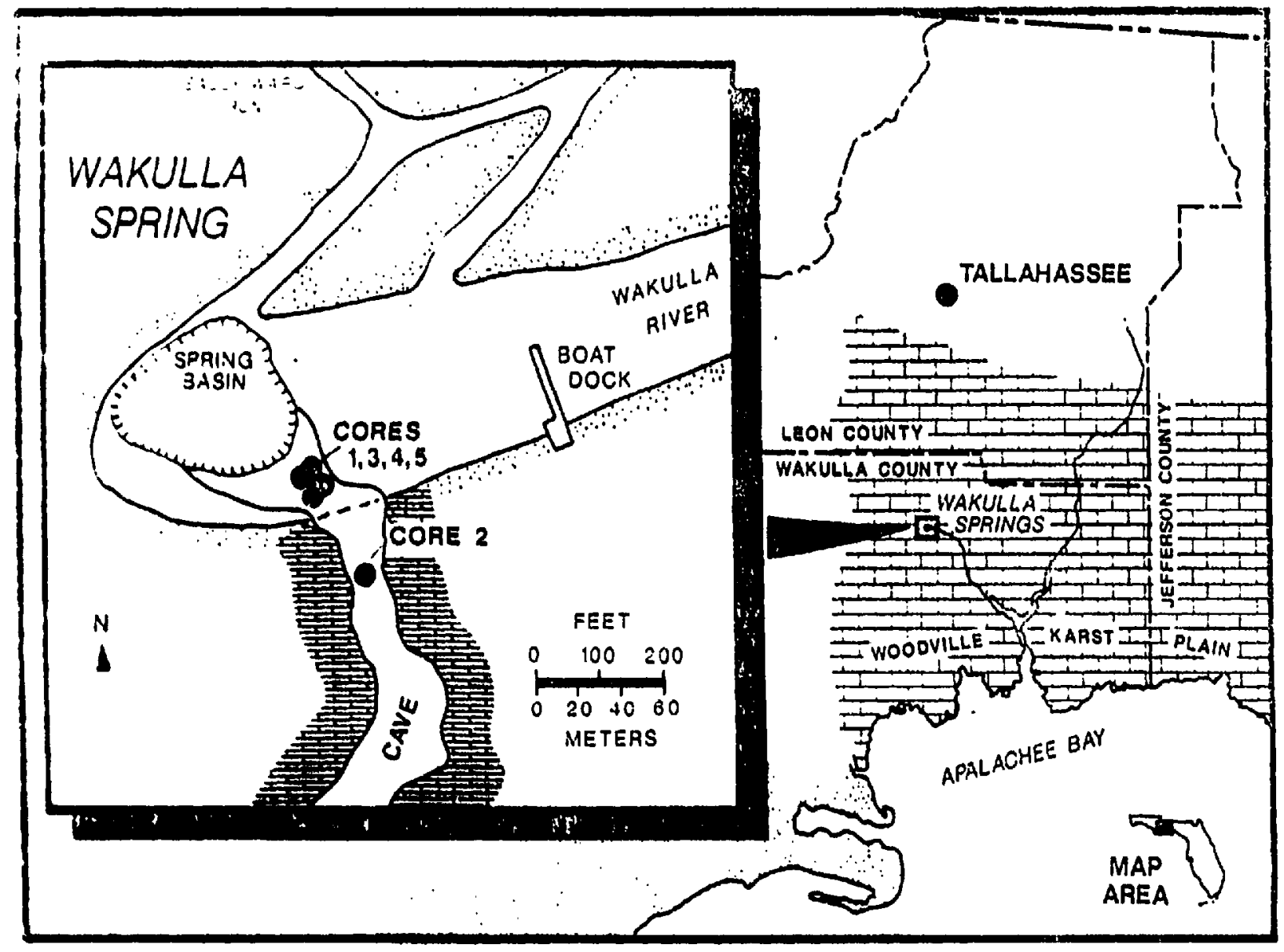

Figure 1. Wakulla Spring and core location map.

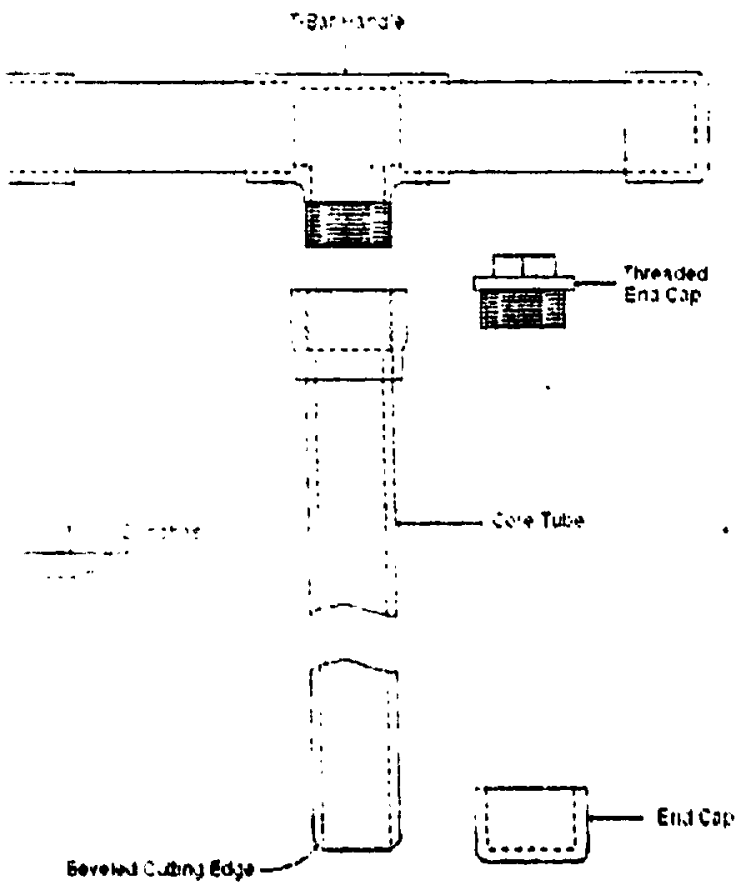

Figure 2. Diagram of 1.5 inch diameler PVC sediment coring tube used in this study (Designed and drafted by William Wilson. Subsurface Evaluations, Inc., Hinter Springs, Florida). 
Ench core was extruded from the sampling tube back on land by pushing a wad of paper towels against the top of the sediment with a broomstick. The cores were then scaled in polyethylene wrapping.

The core packages were later opened and each core was describied lithologically. Lithologic descriptions are provided in the Appendix section of this report. Approximately 100 grams of sediment was cut from selected intervals in the calcilutite portions of five cores for pollen analysis. Only intervals containing sufficient sediment to provide the necessary 100 grams of sample were selected. One sample was taken in each of Cores 1 through 4, and two samples were taken in Core 5. Table 1 includes the intervals sampled in each core. The samples were then sent to the Delaware Geological Survey in Newark for standard pollen-analysis preparation and description. Results of this analysis are shown in Table 1.

$\mathrm{X}$-ray analysis was performed on one sample from Core 2 , taken in the vertebrate bone bed within the main spring cave. This analysis was conducted on a Phillips X-ray diffractometer housed at the Florida State University Geology Department.

The calcilutite intervals in all cores were spot-checked for the presence of diatoms, utilizing temporary water-based smear slides with cover slips: Three samples, comprised of one from Core 2 (4.5" deep) and two from Core 5 ( $5^{\prime \prime}$ and 30" deep) were permanently mounted for detailed diatom analysis. Small portions of sample were disaggregated in sodium hexamctaphosphate solution, shaken, then allowed to settle for 45 seconds. The supernatant solution was then decanted, and the decanted portion centrifuged to concentrate the suspended diatoms. Standard smear slides were then prepared from the centrifuge samples, using the aqueous concentrate with a cover slip for the temporary slides, and Norland Optical Adhesive as the mounting medium for the permanent study slides. Each of slides were scanned for diatoms, and the various species were identified. The species present are discussed in the results section.

\section{Results}

The Wakulla cave floor core sediments are composed principally of medium to coarse grained quartz sand and olive-gray, clay-like calcilutite. The sand intervals contain freshwater gastropod shell tragments (Holisoma sp.) and terrestrial and aquatic plant remains. The calcilutite portions have the appearance of siliciclastic clay when wet. These intervals were found to contain partially decomposed and unidentified plant remains, sand. size limestone particles, and abundant diatom tests.
$X$-ray analysis of the calcilutite interval in Core number 2 was performed to determine its composition. This corc was situated in one of the vertebrate bone beds in the outer portion of the main spring cave. The bulk of the sample is calcitc, with minor quarlz and unidentified clay mineral peaks. Much of this may represent fine breakdown material from the limestone bedrock of the conduits conveying groundwater to the spring.

Table 1 summarizes the major pollen groups present in each of the samples. The numbers shown in Table 1 indicate the percentages of the total pollen sum represented by each pollen type in the samples. A varicty of pollen familics were present, including arboreal angiosperms, conifers, herbs, ferns, and aquatic plants. Dinoflagellates and cysts of green algae were also present in Cores 1 and 2 in low abundance.

Interestingly, the dominant pollen present in all the samples is that of the Chenopodiaceae and Amaranthaceae, two plant families with morphologically similar, periporate pollen grains. In practice, pollen from the various genera in these groups are indistinguishable. Therefore, they are lumped together as "Chenopod/Amaranth" in this report.

The Chenopodiaceae include as modern representatives the glassworts and seablites. These forms are characteristic salt marsh and salt flat nora. The Amaranthaceae include both fresh and brackish water swamp plants. Figure 3 illustrates a Chenopodiaceae/Amaranthaccae pollen grain from the Wakulla Spring sediments.

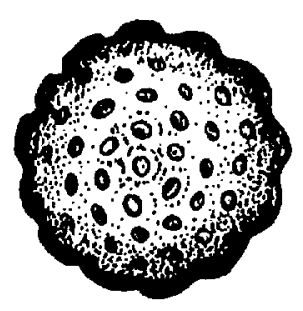

Figure 3. Chenopodiaceae/Amaranthaceae pollen grain (modified from Erdtman, 1954, and based on a photo by Dr. Johan Groot) X1000

The fossil Chenopod/Amaranth type pollen comprised a minimum of 70 percent of the total pollen assemblage (Core 3 ), and ranged up to 82 percent in Core 5, sample 1 . Core 3 contained rare pollen, with most belonging to the Chenopod/Amaranth typc. In Core 5, a group of 8 or 9 undispersed Chenopod/Amaranth pollen, grouped as if in a pollen sac, were observed (Johan Groot, personal communication). Since pollen is generally dispersed rapidly after release, this would 
Table 1. Pollen types present in the Wakulla Spring cores.

\begin{tabular}{|c|c|c|c|c|c|c|}
\hline \multirow{2}{*}{ Intorval Sampled } & \multirow{2}{*}{$\begin{array}{l}\text { Core I } \\
6.16 .5^{\circ}\end{array}$} & \multirow{2}{*}{$\begin{array}{l}\text { Core } 2 \\
0.9^{\circ}\end{array}$} & \multirow{2}{*}{$\begin{array}{l}\text { Core J } \\
18.22^{*}\end{array}$} & \multirow{2}{*}{$\begin{array}{c}\text { Core } 4 \\
5.25 \cdot 12^{*}\end{array}$} & \multicolumn{2}{|c|}{ Core 5} \\
\hline & & & & & & \\
\hline Alnus (hazel alder) & & $\mathbf{P}$ & & & & $\mathbf{p}$ \\
\hline Cany (hickory) & $\mathbf{P}$ & 5 & & 7 & 3 & 2 \\
\hline Collis (sugarberny, hackberry) & $\mathbf{P}$ & & & 1 & $\mathbf{P}$ & \\
\hline \multicolumn{7}{|l|}{ Carpinus-Ostrye (hom bean, nop.hornboan) } \\
\hline Cyrrlla (iiri) & $\mathbf{P}$ & & & & & \\
\hline Liquidumbar (sweetgum) & $\mathbf{p}$ & & 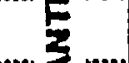 & & 2 & $\mathbf{P}$ \\
\hline Myssa (tupeto. sourgum) & & $\mathbf{P}$ & 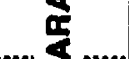 & & $\mathbf{P}$ & $\mathbf{P}$ \\
\hline Salix (WHilow) & 1 & & & & & \\
\hline Tilia (basenwood, linden) & & $\mathbf{P}$ & & $\mathbf{P}$ & & 1 \\
\hline Uimus (oim) & 1 & $\mathbf{P}$ & & $\mathbf{P}$ & $\mathbf{P}$ & \\
\hline Ouercus (ook) & 14 & 9 & i & 8 & ..... & 11 \\
\hline \multicolumn{7}{|l|}{ Conitore } \\
\hline Pinus (pino) & 8 & 1 & 6 & 5 & $\mathbf{p}$ & 1 \\
\hline \multicolumn{7}{|l|}{ Herbs } \\
\hline Chenopodiacoese (ocosefoot family) & 70 & 79 & & 71 & 82 & 73 \\
\hline Composituo (sunfower tamily) & 2 & $\mathbf{P}$ & & 2 & 1 & 3 \\
\hline Graminace (grass family) & & 1 & & $\mathbf{P}$ & & $\mathbf{p}$ \\
\hline Umbelliferee (carrol family) & & $\mathbf{p}$ & & $\mathbf{p}$ & & \\
\hline \multicolumn{7}{|l|}{ Aqualles } \\
\hline \multicolumn{7}{|l|}{ Hydrocheritaceae (aquatlo horbs) } \\
\hline Sparganlum Typha (caltalls) & & 1 & & 2 & $\mathbf{P}$ & 1 \\
\hline \multicolumn{7}{|l|}{ Foms } \\
\hline Ponpodieccese (lem family) & & & & & 4 & 3 \\
\hline Cyete of green algae & $\mathbf{p}$ & 2 & & & & \\
\hline Oinollogellatese & $\mathbf{p}$ & & & & & \\
\hline
\end{tabular}

$P$ indicates less than $1 \%$ of pollen total 
suggest minimal transport of the pollen prior to deposition.

Arborcal plant specics comprisc a maximum of 14 percent of the pollen totals in any sample. Most of the angiosperm tree and conifer species typical of the modern forest surrounding Wakulla Spring today are represented by only small percentages of the fossil pollen in each sample. Quercus (oak) ranges from 4 to 11 percent of the totals. Canya (hickory), where present, ranged from 2 percent of the fossil pollen in Core 5, sample 2 to a maximum of 7 percent in Core 4. Pinus (Pine) comprises less than 1 percent in Core 6, and ranged up to 8 percent in Core 1 . The remaining plant species comprise four percent or less of the pollen assemblages in each sample. Core 3 contained only rare pollen, and most of this was of Chenopod/Amaranth. Green algae cysts were present in Cores 1 and 2, and Dinoflagellates were observed in Core 1.

The diatom species present, with the exception of Paralia $c f$. sulcata (a brackish water to marine species), are reported as common constituents of modern fresh water bodies (United States Department of the Interior, 1966). These include Melosira italica, Gomphonema herculeana, Epithema irregularis, Epithema urgida, Navicula amphibola, Cocconeis placentula, Navicula cuspidala, Symedra ulna, and Pinmularia gibbia.

\section{Discussion}

The fossil pollen present in the Wakulla Spring sediment cores provide insight into the probable Late Pleistocene or Holocene history of the spring. Of particular significance is the overwhelming abundance of the Chenopod/Amaranth pollen in all of the cores. Due to the similarity of pollen from all genera of the families Chenopodiaceae and Amaranthaceae, it is usually not possible to differentiate the genera.

The Chenopodiaceae, or Goosefoot family, are halophytic, and typically inhabit salt and brackish marshes and flats. Three modern indigenous genera of Chenopodiaceae occur in Florida: Chenopodium, Stuaeda and Salicomia (Clewell, 1985). The genus Chenopodium can occur in open inland areas, but also occurs along coastal beach barrens (Clewell, 1981). Both Salicomia and Suaeda are restricted to constal salt marshes, salt Mats or, in some cases, fore-beach areas (Clewell, 1981, 1985).

The Amuranthaceae are typically freshwater swamp plants. One species, Amaranthus australls, is abundant in Florida lakes today (Watts, 1969).
Watts (1969) suggested that the Chenopod/Amaranth type pollen observed in lake bottom cores from Marion Counly, Florida, may be from this species. However, because pollen from the two families is indistinguishable, a paleoenvironmental interpretation is uncertain. The questionable family affinity of the Chenpod/Amaranth pollen in the Wakulla Cave cores poses a problem in interpreting the depositional environment of the cave floor sediments. If the pollen is that of the Amaranths, the sediments may simply be recent, freshwater spring/marsh deposits. This is supported by the presence of freshwater gastropod (Helisoma sp.) shells and diatoms throughout the sediments in the cores.

If the pollen are from the Chenopodiaccac. a case may also be made for a brackish water influence. Intuitively, one explanation for the possible presence of Chenopodiaceae pollen in the Wakulla Spring sediments is a marine transgression, which would have shifted a coastal saltmarsh environment landward to the present vicinity of Wakulla Springs.

Two late Quaternary marine transgressions are documented in the local geologic record. One was the Late Pleistocene Pamlico sea level (Sangamon Interglacial Period) highstand, which stood approximately 25 feet above present sea level.

The Pamlico transgression corresponded to an interglacial warm period, the Sangamon, which pre-dates the most recent glacial period (Wisconsinian) of the Pleistocene Epoch. Isotope age dates from shell material collected in elevationally-similar Pamlico terrace deposits on Florida's cast coast indicatc sea level high stands occurring at 130,000 and 85,000 years before present (Osmond et al., 1965; 1970).

The Pamlico sea flooded large areas of Florida, and inundated most of castern Wakulla County (Figure 4a). Many of the relict bars, dunes and beach ridges shaping the surface of central and eastern Wakulla County today werc probably associaled with the Pamlico sea. The shoreline likely fluctuated through time in an elevation range of 10 to 25 feet above present sea level (MacNcil, 1950; Healy, 1975). This range placed the palcoshoreline close 10, and at limes north of Wakulla Spring. A saltmarsh environment, probably similar to the modern marshes of southern Wakulla County, could have fringed the Pamlico shore. 


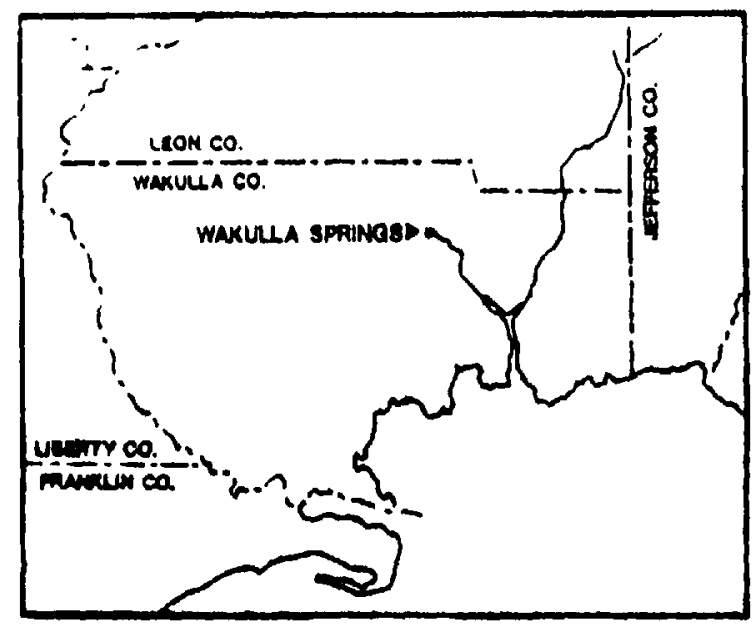

Figure ta. Approximate extent of the Pamlico (Pleistucene) sea (modified from MacNeil, 1950; Healy. 1975).

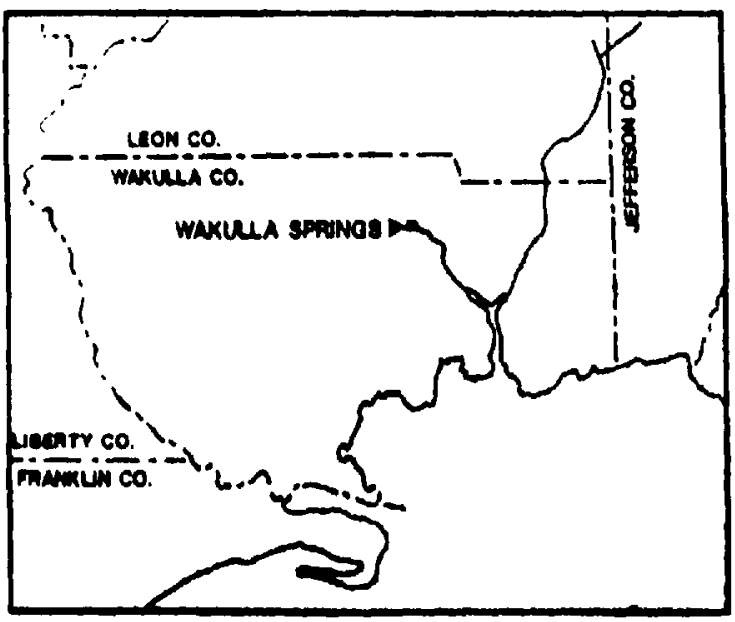

Flgurs 4b. Approximate extent of the Silver Bluff (Holocene) sea (modified from MacNeil, 1950; Healy, 1975).

While the age of formation of Wakulla Spring is uncertain, present data suggest it was most likely present and nowing freshwater during the period in which the Chenopods grew nearby, perhaps mixing with the Gulf waters and creating a localized brackish environment in the immedinte area of the spring. The paleo-freshwater flow in the spring is evidenced by the very abundant freshwater diatom assemblage contained within and intermixed with the pollen in the core samples. The diatom species present are common constituents of many modern freshwater bodies (United States
Department of the Interior, 1:66).

A sccond transgression of lesser magnitude, possibly corresponding to the Silver Blufr Sea, occurred in the middle Holocene, about 4,500 years ago (Stapor and Tanncr, 1977; Tanner et al., 1989). This highstand is documented in beach deposits along the panhandle coast of Florida. Beach ridge and scarp elevation data and Carbop-14 dates on associated archaeological artifacts from St. Vincent Island (southwest of Wakulla Spring in Franklin County, Florida) and adjacent mainland indicate this highstand reached a height of about 5 feet nbove modern sea level. Based on the modern topography, a five.feet sea level rise would have produced a marine transgression up the Waiulta River valley, reaching the spring, but being restricted for the most part to the river valley itseif Figure 4b). Whether this transgression was adequate 10 produce the inundation and water salinity necessary to develop a salt marsh environment around Wakulla Spring is unccrtain. The topography near Wakulla Spring today risus rapidly from elevations of about 5 feet above niean sea level immediately around the spring pool to about 25 feet above mean sea level at the tops of nearby gently-rolling sand hills. It appears unlikely that such topography would have provided the unobstructed saltwater interchange necessary to maintain a saltmarsh environment.

Unfortunately, there are no age-dateable materials associated with the Wakulla Spring samples. The timing of such a transgressicn is therefore uncertain. The polien species prescnt do not provide a definitive age zone, but the absc.xce of exotic fle-- allen in the core samples suggests a Quatert . ze for the cave thoor sediments (Johan Groot, personal communication). Additionally, in light of the seemingly in-place nature of the sediments, it seems unlikely that shallow, unconsolidated sediments such as these could survive undisturbed in an actively flowing, subaqueous, environment from a time earlier than the late Quaternary.

A transition from a brackish salt flat ecosystem to terrestrial forest is not documented in the pollen record of the present samples. This may, in part, be due to removal by erosion of portions of the cave sediments. In addition, the large sample interval required to obtain adequate quantities of sediment for polten analysis from the small diameter cores taken in this study may have obscured significant floral transitions. Future core studies using larger diameter cores and smaller sample intervals might better delineate temporal pollen changes in the cave floor sediments. 
The Florida Geological Survey hopes to continuc this study with future acquisition of additional sediment cores from Wakulla Spring during the tentatively-scheduled 1992 Wakulla Springs Expedition. In addition, similar sediment cores may be obtained during concurrent studies in Indian Spring, located one-milc northwest of Wakulla Spring. Cores from an adjacent spring should provide further insights on the extent, age, and type of Quaternary paleoenvironmerits observed in the Wakulla Spring area.

\section{Acknowledgements}

A number of individuals contributed their time and expertise to make this study possibie. Special thanks are extended to Dr. Bill Stone and Mr. Wes Skiles for incorporating the core sampling into the 1987 Wakulla Springs Exploration Project, and to the Florida DNR Division of Recreation and Parks, especially Mr. Ellison Hardec, Mr. Dana Bryan, and Mr. Dick Miller for pennitting the sediment coring on State Park property. Mr. Bill Wilson coordinated the cave mouth core sampling lent his time and specialized coning device to the collection effort, and critically reviewed a draft of the manuscript. Mr. Tom Morris assisted in collecting the cave-mouth cores, and Mr. Wes Skiles and Mr. Fred Davis were extremely helpfill in collecting the two cores from the bone bed area within the main cave. Many thanks are also due Dr. Johtan Groot and the palynological lab staff at the Delaware Geological Sunvey for the preparation, examination, and interpretation of the pollen assemblages in the core samples. The author is grateful to the following individuals for reviewing drafts of this manuscript: Drs. Walter Sclumidt and Toin Scott, and Mr. Ed Lane of the Florida Geological Survey, and Mr. Bill Bartodziej of the FDNR, Bureau of Aquatic Plant Management.

\section{References}

Clewell, A.F., 1981, Natural setting and vegetation of the Florida panhandle: 'A report prepared under contract No. DACW01-77. C-0104, U.S. Army Corps of Engineers, Mobile, Alabama, $737 \mathrm{p}$.

Clewell, A.F., 1985, Guide to the vascular plants of the Florida panhandle: Tallahassee, Florida State University Press, p. 269-271.

Erdtman, G., 1954, An introduction to pollen analysis: Waltham, Chronica Botanica Company, $239 \mathrm{p}$.

Godfrey, R.K., and Wooten, J.W., 1981, Aquatic and wetland plants of southeastern United States: Athens, University of Georgia Press, p. 93-101.
Healy, H.G., 1975, Terraces and shorelines of Florida: Florida Burcau of Gicology Map Series 71.

MacNeil, F.S.. 1950, Pleistocene shorelines in Florida and Georgia: U.S. Geological Survey Professional Paper 221-F, p. 95-107.

Olsen, S., 1958, The Wakulla Cave: Natural History, v, 67, n. 7, p. $\quad 396-403$.

Osmond, J.K., Carpenter, J.R., and Windom, H.L., 1965, $\mathrm{Th}^{230} / \mathrm{U}^{234}$ age of the Pleistocene corals and oolites of Florida: Journal of Geophysical Research, v. 70, n. 8, p.18431847.

May, J.P., and Tanner, W.F., 1970, Age of the Cape Kennedy barricr-and-lagoon complex: Journal of Gcophysical Rescarch, v. 75, n.2, p. 469-479.

Rosenau, J.C., Faulkner, G.L., Hendry, C.W. and Hull, R.W.. 1977, Springs of Florida: Florida Bureau of Geology Bulletin 31 (revised), p. 415-424.

Rupert, F.R., and Spencer, S. M., 1988, The geology of Wakulla County, Florida: Florida Geological Survey Bulletin 60, 46 p.

Stapor, F.W., and Tanner, W.F., 1977, Late Holocene mean sea level data from St. Vincent Island and the shape of the late Holocene mean sea level curve: in: Proceedings, Coastal Sedimentology Symposium, Florida State University, Department of Gcology, p. 35-68.

Stone, W.C. (ed.), 1989, The Wakulla Springs Project: Austin, Raines Graphics, 212 p.

Tanner, W.F., Demirpolat, S., and Alvarez, L., 1989, The "Guif of Mexico" Late Holocene sea level curve: Transactions-Gulf Coast Association of Geological Societies, v. 39, p.553-562.

United States Department of the Interior, 1966, A guide to the common diatoms at water pollution surveillance system stations: Federal Water Pollution Control Administration, Water Pollution Surveillance, 1014 Brondway, Cincinnati, $\mathrm{OH}, 45202$, June, 1966, $101 \mathrm{p}$.

Watts, W.A., 1969, A pollen diagram from Mud Lake, Marion County, north-central Florida: Geological Society of America Bulletin, v. 80, p.631-642. 


\section{APPENDIX}

\section{Lithologic descriptions of cave floor sediment cores}

Core 1

Lithologic Description:

Denth:

1). 0.3 .3 in. $(0.0-3.6 \mathrm{~cm})$

3.3 .56 in. $(\$ .4-14.2 \mathrm{~cm})$

$5.0-12.0 \mathrm{in} .(14.2 \cdot 30.5 \mathrm{~cm})$

$12.0 \cdot 13.1$ in. $(30.5 \cdot 33.3 \mathrm{~cm})$

$13.1-16.5$ in. $(33.3-41.2 \mathrm{~cm})$
Water Depth: 140 feet $(42.6 \mathrm{~m})$

Length: 16.5 in. $(41.2 \mathrm{~cm})$

Collected by William Wilson, 11-14-87.
Litholony:

Dusky yellowish brown (10YR 2/2) organic-rich calcilutitc, containing abundant brown plant remains and freshwater gastropod (Helisoma sp.) shell fragments.

Olive gray $(5 Y 4 / 1)$ organic rich calcilutite, containing abundant plant rer:ains, shell fragments, and limestone fragments. Interval 5.4-5.6 in. composed of matted brown plant remains intermixed with calcilutite.

Dusky yellowish brown (10YR 2/2) organic rich calcilutite, containing abundant plant remains, wood fragments, and limestone and freshwater gastropod shell fragments.

Olive gray $(5 Y+/ 1)$, organic rich, fine to medium quartz sand, containing freshwater shell fragments.

Dusky yellowish brown (10 YR 2/2), organic rich calcilutitc, containing limestone granules, freshwater shell fragments, and diatoms.
Core 2

$0.0-9.5$ in. $(0.0-24.1 \mathrm{~cm})$
Water Depth: 195 fect $(59.4 \mathrm{~m})$

Length: 9.5 in. $(24.1 \mathrm{~cm})$

Collected by Fred Davis, 12-28-87, in vertebrate bone bed, 285 feet inside cave.

\section{Core 3}

$0.0-13.5 \mathrm{in} .(0.0-34.3 \mathrm{~cm})$
Water Depth: 140 feet $(42.7 \mathrm{~m})$

Length: 23.1 in. $(58.7 \mathrm{~cm})$

Collected by William Wilson, 11-15-87.

Dusky yellowish brown (10YR $2 / 2$ ) organic rich calcilutite, containing abundant plant remains, limestone particles, and rare ostracode shells.

(contimued on next page) 
Core 3, continued:

$13.5-15.3$ in. $(34.3-38.7 \mathrm{~cm})$

$15.3-17.8$ in. $(38.7-45.2 \mathrm{~cm})$

$17.8-21.5$ in. $(45.2-54.6 \mathrm{~cm})$

$21.5 \cdot 23.1$ in $(54.6 \cdot 58.7 \mathrm{~cm})$
Yellowish gray (5Y 8/1), fine to medium quartz sand containing plant remains. Bedding in core angled approximately $45^{\circ}$ to the horizontal; probably a slope deposit.

Olive black (5Y 2/1) calcilutite containing abundant plant remains.

Yellowish gray (5Y 8/1), fine to medium quartz sand, with interbedded calcilutite, and containing plant remains, limestone particles, and reworked Oligocene foraminifera.

White (N9) to yellowish gray (5Y 8/1) calcarenitic limestone, containing abundant Oligocene foraminifera (Core bottomed on Suwannee Limestone).

\section{Core 4}

$0.0-4.3$ in. $(0.0-10.9 \mathrm{~cm})$

4.3-12.4 in. $(10.9-31.5 \mathrm{~cm})$

$12.4-17.5$ in. $(31.3-44.5 \mathrm{~cm})$

17.5-24.1 in. $(44.5-61.2 \mathrm{~cm})$
Water Depth: 140 feet $(42.7 \mathrm{~m})$

Length: 24.1 in $(61.2 \mathrm{~cm})$

Collected by William Wilson, 11-15-87.

Dark yellowish brown (10YR 4/2), very fine quartz sand, containing abundant freshwater gastropod shells, sheil fragments, limestone particles, and organics. Mollusk shell hash intervals present between .5 and $2.0 \mathrm{in} .(1.3-5.1 \mathrm{~cm})$ and between 3.3 and $4.1 \mathrm{in}$. $(8.4$ and $10.4 \mathrm{~cm})$.

Dark yellowish brown (10YR 4/2), unconsolidated organic rich calcilutite, containing approximately $10 \%$ very fine to fine quartz sand.

Yellowish gray (5Y 8/1), fine to medium quartz sand, containing mollusk shell fragments, limestones fragments, and organics.

Pale yellowish brown (10YR 6/2), very fine to fine quartz sand with calcilutite matrix. Contains mollusk shell and limestone fragments, abundant plant remains, and well-preserved Oligocene Suwannee Limestone foraminifera eroded from underlying limestone.

\section{Core 5}

$0.0-31.0$ in. $(0.0-78.7 \mathrm{~cm})$

$2 / 2)$

\author{
Water Depth: 135 feet $(41.2 \mathrm{~m})$ \\ Length: 31 in. $(78.7 \mathrm{~cm})$ \\ Collected by William Wilson, 1987.
}

Dark yellowish brown (10YR 4/2) to dusky yellowish brown (10YR organic rich calcilutite, containing abundant plant remains and limestone particles. Abundant diatoms at $10.0 \mathrm{in} .(25.4 \mathrm{~cm})$.

Note: Color designation codes are taken from The Rock-Color Chart Committec, 1984, Rock-Color Chart: Geological Society of America, P.O. Box 9140, Boulder, CO, 80301. 